Review Article

\title{
Synergistic Effects of Vascular Endothelial Growth Factor on Bone Morphogenetic Proteins Induced Bone Formation In Vivo: Influencing Factors and Future Research Directions
}

\author{
Bo Li, ${ }^{1}$ Hai Wang, ${ }^{1}$ Guixing Qiu, ${ }^{1}$ Xinlin Su, ${ }^{1}$ and Zhihong $\mathrm{Wu}^{1,2,3}$ \\ ${ }^{1}$ Department of Orthopaedic Surgery, Peking Union Medical College Hospital, Peking Union Medical College and \\ Chinese Academy of Medical Sciences, No. 1 Shuaifuyuan, Beijing 100730, China \\ ${ }^{2}$ Central Laboratory, Peking Union Medical College Hospital, Peking Union Medical College and Chinese Academy of Medical Sciences, \\ No. 1 Shuaifuyuan, Beijing 100730, China \\ ${ }^{3}$ Beijing Key Laboratory for Genetic Research of Bone and Joint Disease, No. 1 Shuaifuyuan, Beijing 100730, China
}

Correspondence should be addressed to Zhihong Wu; wuzh3000@126.com

Received 7 August 2016; Revised 16 October 2016; Accepted 24 October 2016

Academic Editor: Martín F. Desimone

Copyright (C) 2016 Bo Li et al. This is an open access article distributed under the Creative Commons Attribution License, which permits unrestricted use, distribution, and reproduction in any medium, provided the original work is properly cited.

\begin{abstract}
Vascular endothelial growth factor (VEGF) and bone morphogenetic proteins (BMPs), as key mediators in angiogenesis and osteogenesis, are used in a combined delivery manner as a novel strategy in bone tissue engineering. VEGF has the potential to enhance BMPs induced bone formation. Both gene delivery and material-based delivery systems were incorporated in previous studies to investigate the synergistic effects of VEGF and BMPs. However, their results were controversial due to variation of methods incorporated in different studies. Factors influencing the synergistic effects of VEGF on BMPs induced bone formation were identified and analyzed in this review to reduce confusion on this issue. The potential mechanisms and directions of future studies were also proposed here. Further investigating mechanisms of the synergistic effects and optimizing these influencing factors will help to generate more effective bone regeneration.
\end{abstract}

\section{Introduction}

Globally, approximately 15 million fractures are reported per year $[1,2]$, with $5-10 \%$ nonunion rate $[1,3,4]$. In addition, other diseases including tumors, infections, and degenerative diseases may also lead to bone defect. Bone is the second most commonly transplanted tissue, preceded only by blood transfusion [1]. Bone grafts performed in the United States alone are approximately 1.6 million per year, bringing huge medical and economic burden [2]. A variety of strategies have been developed to repair the diseased or defected bone. Autografts, which can provide desired growth factors, cells, and even microcirculation system, have always been regarded as the gold standard $[3,5,6]$. Unfortunately, autografts are restricted by some disadvantages, such as limited donor availability and donor-site morbidity $[3,6]$. Allografts and xenografts as alternatives are limited by the potential disease transmission and immune rejection $[3,6,7]$. Tissue engineering is generally considered as a promising technique to overcome the disadvantages of traditional therapies.

A major objective of bone tissue engineering is to get effective bone regeneration, which is related to successful osteoinduction. Osteogenic cytokines, such as bone morphogenetic proteins (BMPs) and platelet-derived growth factor (PDGF), are the ideal candidates to enhance the osteoinduction $[8,9]$. BMPs, identified and named by Urist $[10,11]$, belong to transforming growth factors $\beta$ (TGF- $\beta$ ) superfamily. The osteogenic ability of BMPs has been welldocumented in literatures [12]. Among them, BMP2, BMP4, BMP6, BMP7, and BMP9 possess osteogenic properties [12, 13]. Furthermore, rhBMP2 and rhBMP7 have been approved by FDA (US Food and Drug Administration) for specific clinical applications $[12,14]$. However, in the last few years, some studies showed that desired clinical results could not 


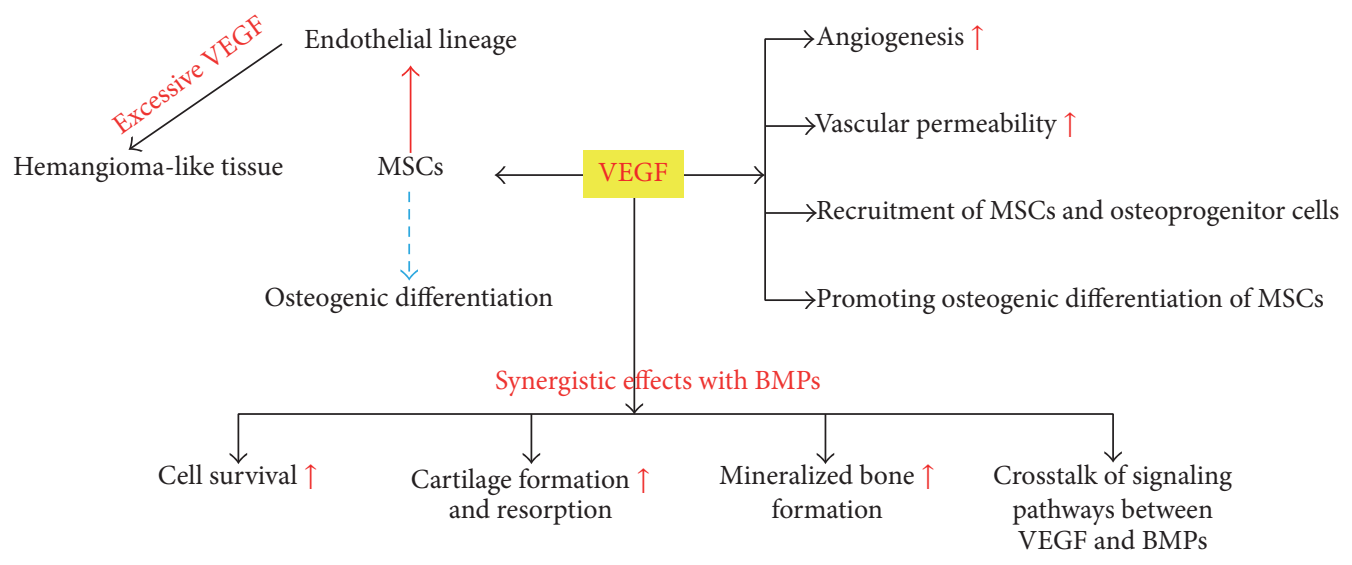

FIGURE 1: The role of VEGF on BMPs induced bone formation.

been obtained by using BMPs alone. Moreover, complications caused by high-dose application were worrisome [3, 15-18].

Blood supply is arguably the largest challenge for any tissue engineering $[25,26]$. Within the body, the effective diffusion distance of oxygen and nutrients is no more than $200 \mu \mathrm{m}$ from the nearest capillary [25-27]. Bone is a highly vascularized tissue. Reconstructing local microcirculation is prerequisite for effective bone regeneration [28]. Inhibiting angiogenesis will reduce bone formation [29-31], while promoting angiogenesis can enhance bone regeneration [32]. Angiogenesis is regulated by several angiogenic factors, such as fibroblast growth factors (FGFs), transforming growth factor- $\alpha / \beta$ (TGF- $\alpha / \beta)$, PDGF, and notably vascular endothelial growth factor (VEGF) [15, 33-37]. Gerber et al. [29] investigated the role of VEGF in angiogenesis and bone formation. Their results shown that vascular invasion and bone formation were both suppressed by inhibiting VEGF in 24-day-old mice [29]. It was also revealed that application of VEGF-specific antagonist (soluble Flt1) could inhibit the bone regeneration induced by BMP 4 and BMP2 $[19,20]$.

The undesirable outcomes of using BMPs alone and the importance of blood supply inspire tissue engineering scientists to explore the combined application of osteogenic and angiogenic factors $[15,38-40]$. One of the most studied directions is the codelivery of BMPs and VEGF. The addition of VEGF is expected to enhance bone formation and reduce the amount of BMPs used.

\section{The Combined Application of VEGF and BMPS}

2.1. The Role of VEGF on BMPs Induced Bone Formation. As a key mediator of angiogenesis [15, 38], VEGF also has direct and indirect effects on bone formation [7, 43]. VEGF may increase vascular permeability after promoting local angiogenesis $[43,49]$. This will facilitate the recruitment of mesenchymal stem cells (MSCs) and osteoprogenitor cells to indirectly enhance the ability of bone regeneration [7, 43]. VEGF can also directly attract MSCs and promote their osteogenic differentiation [7, 43]. Enhanced neovascularization and bone regeneration were induced by the controlled release of VEGF in the study of Kaigler et al. [32]. After blocking VEGF, angiogenesis and osteogenesis were both inhibited $[19,20]$. In addition to increasing angiogenesis and recruitment of MSCs, VEGF can act synergistically with BMPs to enhance cell survival, cartilage formation and resorption, and mineralized bone formation [19, 20]. Recently, the cross-talk of signaling pathways between VEGF and BMPs has gained growing attention $[15,50,51]$. Studies indicated that the synergistic effects of VEGF on BMPs induced bone formation were not only due to the increased angiogenesis (Figure 1). After the activation of VEGF signaling, the response of MSCs to BMP6 was significantly enhanced both in vitro and in vivo $[15,23,51]$. When treated with VEGF and BMP6, the expression of osteogenic genes including ALP, Dlx5, and osterix was significantly upregulated [50]. Furthermore, BMP-nonresponsive osteoprogenitor cells responded well to the costimulation of VEGF and BMP6 [51]. However, the accurate mechanisms are still unknown.

2.2. Controversy on the Synergistic Effects between VEGF and $B M P s$. Although many studies have focused on this issue, whether VEGF can enhance BMPs induced bone formation in vivo is still very controversial [46]. The variation of influencing factors in different studies has led to completely opposite results, bringing much confusion on this issue. Based on literatures in this field, several important factors (Figure 2), which can significantly influence the synergistic effects between VEGF and BMPs, were identified and analyzed in the present review. These factors could partly explain the variations in the results of different studies and provide important information for future studies to generate more effective bone regeneration.

\section{Influencing Factors}

3.1. BMPs. Among BMP family, BMP2, BMP4, BMP6, BMP7, and BMP9 possess osteogenic properties [12, 13, 52-54]. They may share some properties in osteoinductive activity, but their interactions with VEGF are distinct. Synergistic effect of BMP4 with VEGF on bone formation is quite different from that of BMP2. Osteogenic effect of BMP4 was significantly 


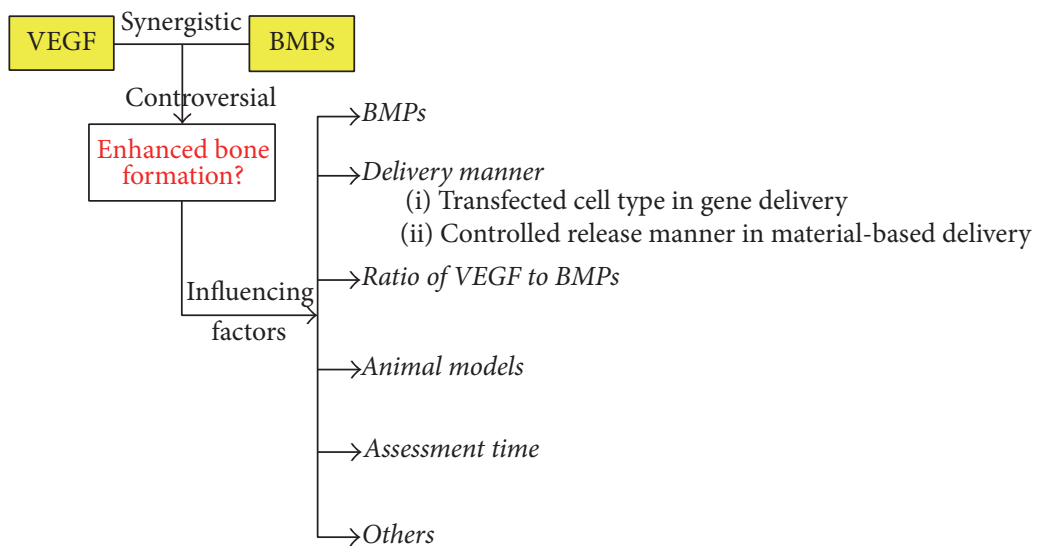

FIGURE 2: Factors influencing the synergistic effects between VEGF and BMPs.

affected by exogenous VEGF and it was more sensitive to the ratio of VEGF to BMP4 $[19,20]$. High ratio of VEGF/BMP4 was obviously detrimental to the mineralized bone formation [19]. However, BMP2 could induced well-formed mineralized bone under high ratio of VEGF/BMP2, although the amount of bone formation also decreased compared to the group with lower ratio of VEGF/BMP2 [20]. The reason why BMP2 is less sensitive to VEGF remains unclear. A possible explanation is that BMP2 itself possesses angiogenic activity, leading to a decreased reaction to VEGF [20].

3.2. Delivery Manner of VEGF and BMPs. Traditional administration of growth factors is limited by their relatively short half-lives and potential side effects [55-57]. To overcome these disadvantages, gene delivery $[6,58-63]$ and materialbased delivery system [64-70] have been developed in tissue engineering. There are mainly two strategies used in the codelivery of VEGF and BMPs. One of them is the expression of transgenes [19, 71-75] and the other is controlled release of growth factors from specific materials [38, 67, 76-78]. Transfected cell types in gene delivery and controlled release manners in material-based delivery can obviously influence the synergistic effects of VEGF and BMPs.

3.2.1. Transfected Cell Types in Gene Delivery. For transgenes therapy, plasmid, virus, and transfected cells are usually used as vectors or carriers for sustained expression of VEGF and/or BMPs [19-24, 79, 80] (Table 1). When transfected cells are transplanted in vivo, the synergistic effects of VEGF on BMPs induced bone formation are cell-type dependent. Peng et al. [19] transfected muscle-derived stem cells (MDSCs) to express VEGF or BMP4. Combined transplantation of VEGF- and BMP4-expressing cells resulted in significantly more bone formation compared to transplantation of BMP4expressing cells alone [19]. Human periosteum-derived cells, osteoprogenitor cells, and bone marrow stromal cells (BMSCs) have been also proven to be effective carriers to achieve the synergistic effects between VEGF and BMPs [21, $23,79]$. However, when C2C12 cells (mouse myoblasts) and $\mathrm{NIH} / 3 \mathrm{~T} 3$ cells (mouse fibroblasts) were transfected to express BMP4 or VEGF + BMP4, VEGF inhibited the calcification of cells in vitro and exhibited a detrimental effect on bone formation in vivo [22].

3.2.2. Controlled Release Manners in Material-Based Delivery. Studies have adopted different controlled release manners for delivering VEGF and BMPs to investigate their synergistic effects [7, 13, 41-48, 81-83] (Table 2). Biomaterials, such as gelatin, chitosan, collagen and poly (lactic-co-glycolic acid) (PLGA), can serve as carriers to release growth factors in a sustained manner in vivo [38, 84-87]. The controlled drug delivery system can be incorporated into porous materials to form a hybrid bone substitute scaffold, which can fill bone defect and induce effective bone repair. During normal bone regeneration, the expression of VEGF is upregulated in the early days and peaks around day 5-10 [43, 88-90], while normal expression of BMPs peaks at day 21 and thereafter [43, $91,92]$. In order to achieve the sequential release of growth factors, Kempen et al. [43] adopted PLGA microspheres and poly (propylene) scaffold as a sustained release system of BMP2 and used gelatin hydrogel as a fast release system of VEGF. The in vivo release profiles of VEGF showed an initial burst release in the first 3 days $(89.9 \pm 2.9 \%$ at the ectopic site). The remaining VEGF exhibited a sustained release over 35 days at a low level. The release of BMP2 was sustained over 56 days [43]. Ectopic bone formation was significantly enhanced by the combined application of VEGF and BMP2 compared to that of BMP2 alone [43]. However, some other authors supported more sustained delivery (nonfast release) of VEGF [7, 32]. The effect of fast release of VEGF is still controversial. The vascular network induced by VEGF alone is immature [26, 93-95]. If its concentration falls too low before the formation of mature vascular network, the unstable vascular network may be remodeled or trimmed $[42,95,96]$. This is also supported by the results of previous studies that synergistic effect of VEGF and BMP2 was only presented at 4 weeks in vivo, while being absent at 12 weeks [42]. In both groups of VEGF alone and VEGF + BMP2, a decrease of vascular density was observed at 12 weeks compared to that at 4 weeks [46]. In fact the effective delivery manner of VEGF in the study of Kempen et al. [43] is more like a composite model: burst release in the early stage and 


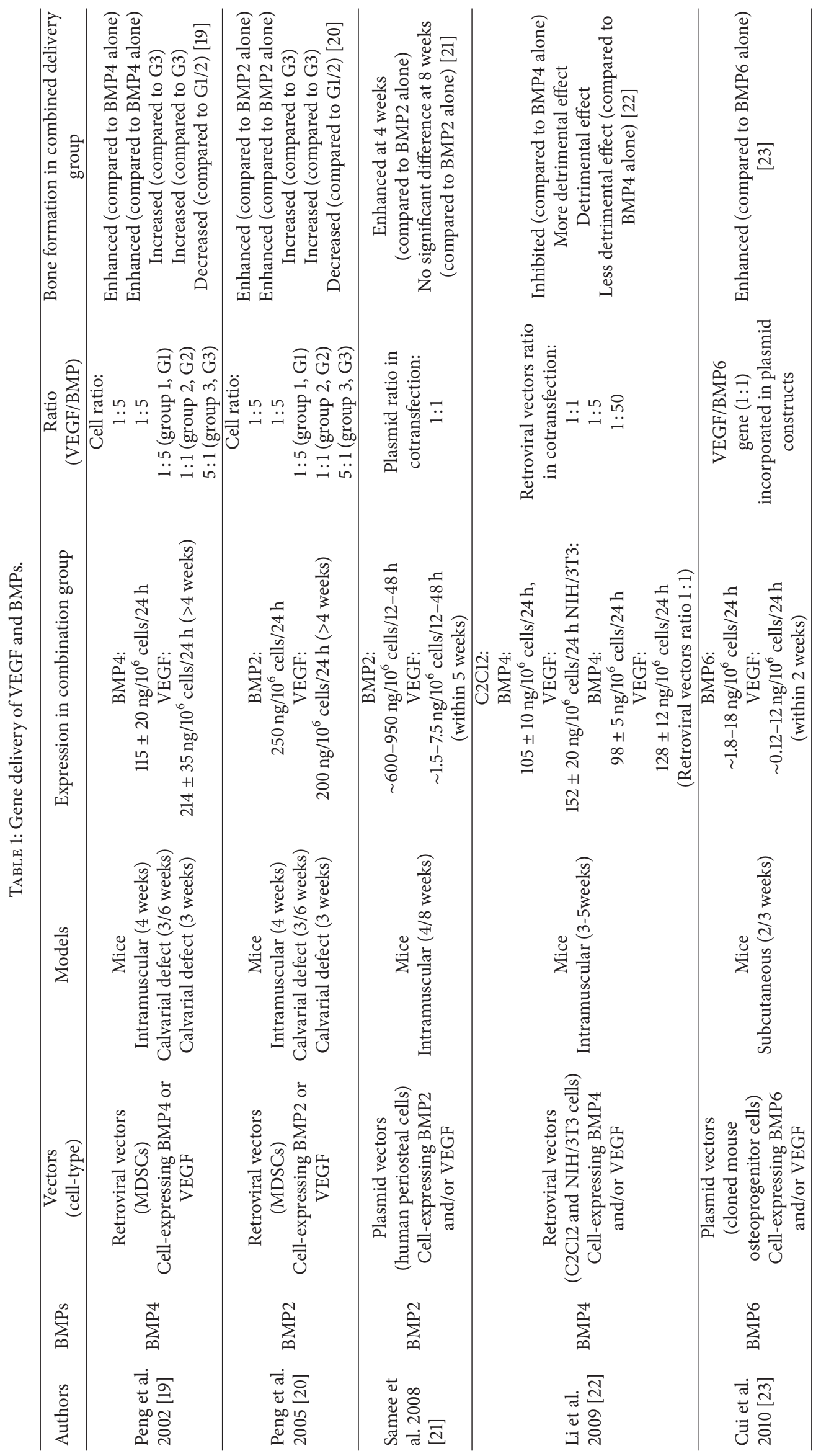




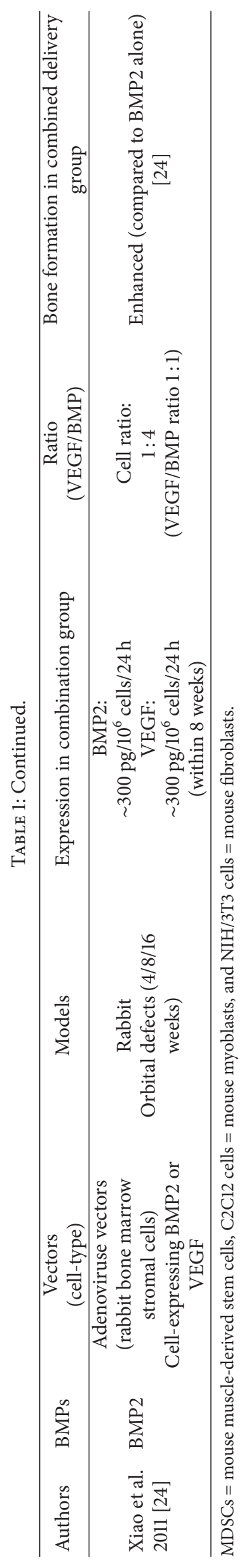


TABLE 2: Controlled release VEGF and BMPs.

\begin{tabular}{|c|c|c|c|c|c|c|}
\hline Authors & BMPs & Carrier & Models & $\begin{array}{c}\text { Combination } \\
\text { delivery }\end{array}$ & $\begin{array}{c}\text { Ratio } \\
(\mathrm{VEGF} / \mathrm{BMP}) \\
\end{array}$ & $\begin{array}{c}\text { Bone formation in } \\
\text { combined delivery group }\end{array}$ \\
\hline $\begin{array}{l}\text { Kakudo et al. } \\
2006 \text { [41] }\end{array}$ & BMP2 & Collagen & $\begin{array}{c}\text { Rat } \\
\text { Intramuscular (3 weeks) }\end{array}$ & Simultaneous & $1: 2$ & $\begin{array}{c}\text { Enhanced (compared to } \\
\text { BMP2 alone) } \\
{[41]}\end{array}$ \\
\hline $\begin{array}{l}\text { Patel et al. } \\
2008 \text { [42] }\end{array}$ & BMP2 & Gelatin & $\begin{array}{c}\text { Rat } \\
\text { Calvarial defect (4/12 } \\
\text { weeks) }\end{array}$ & Simultaneous & $6: 1$ & $\begin{array}{c}\text { Enhanced at } 4 \text { weeks } \\
\text { (compared to BMP2 } \\
\text { alone) } \\
\text { No significant difference } \\
\text { at } 12 \text { weeks (compared to } \\
\text { BMP2 alone) } \\
{[42]}\end{array}$ \\
\hline $\begin{array}{l}\text { Kempen et al. } \\
2009 \text { [43] }\end{array}$ & BMP2 & $\begin{array}{l}\text { PLGA-BMP2 (sustained } \\
\text { release) } \\
\text { Gelatin-VEGF (fast release) }\end{array}$ & $\begin{array}{c}\text { Rat } \\
\text { Subcutaneous (8 weeks) } \\
\text { Segmental femoral } \\
\text { defect (8 weeks) }\end{array}$ & Sequential & $1: 3.3$ & $\begin{array}{c}\text { Ectopic: } \\
\text { enhanced (compared to } \\
\text { BMP2 alone) } \\
\text { Orthotopic: } \\
\text { no significant difference } \\
\text { (compared to BMP2 } \\
\text { alone) } \\
{[43]} \\
\end{array}$ \\
\hline $\begin{array}{l}\text { Young et al. } \\
2009[44]\end{array}$ & BMP2 & Gelatin & $\begin{array}{c}\text { Rat } \\
\text { Calvarial defect (12 } \\
\text { weeks) }\end{array}$ & Simultaneous & $6 / 12 / 24: 1$ & $\begin{array}{c}\text { No significant difference } \\
\text { (compared to BMP2 } \\
\text { alone) } \\
{[44]}\end{array}$ \\
\hline $\begin{array}{l}\text { Roldán et al. } \\
2010 \text { [45] }\end{array}$ & BMP7 & $\begin{array}{l}\text { BCP scaffold (growth } \\
\text { factors injected in the } \\
\text { scaffolds) }\end{array}$ & $\begin{array}{c}\text { Mice } \\
\text { Subcutaneous (12 weeks) }\end{array}$ & Simultaneous & $2: 5$ & $\begin{array}{c}\text { No significant difference } \\
\text { (compared to BMP7 } \\
\text { alone) } \\
{[45]}\end{array}$ \\
\hline $\begin{array}{l}\text { Zhang et al. } \\
2011 \text { [7] }\end{array}$ & BMP2 & Silk hydrogels & $\begin{array}{c}\text { Rabbits } \\
\text { Sinus floor elevation } \\
\text { model (4/12 weeks) } \\
\end{array}$ & Simultaneous & $2: 3$ & $\begin{array}{c}\text { Enhanced (compared to } \\
\text { BMP2 alone) } \\
{[7]} \\
\end{array}$ \\
\hline $\begin{array}{l}\text { Geuze et al. } \\
2012[13]\end{array}$ & BMP2 & $\begin{array}{l}\text { PLGA-VEGF/BMP2 (fast } \\
\text { release) } \\
\text { Gelatin-VEGF/BMP2 } \\
\text { (sustained release) }\end{array}$ & $\begin{array}{c}\text { Dog } \\
\text { Ectopic: } \\
\text { intramuscular ( } 9 \text { weeks) } \\
\text { Orthotopic site: ulnar } \\
\text { defect ( } 9 \text { weeks) }\end{array}$ & $\begin{array}{l}\text { Sequential or } \\
\text { simultaneous }\end{array}$ & $1: 30$ & $\begin{array}{c}\text { No significant } \\
\text { enhancement effect } \\
\text { (compared to BMP2 } \\
\text { alone) } \\
{[13]} \\
\end{array}$ \\
\hline $\begin{array}{l}\text { Hernández et } \\
\text { al. } 2012 \text { [46] }\end{array}$ & BMP2 & PLGA & $\begin{array}{c}\text { Rabbit } \\
\text { Intramedullary femur } \\
\text { defect (4/12 weeks) }\end{array}$ & Simultaneous & $1: 10 / 50$ & $\begin{array}{c}\text { Enhanced at } 4 \text { weeks } \\
\text { (compared to BMP2 } \\
\text { alone) } \\
\text { No significant difference } \\
\text { at } 12 \text { weeks (compared to } \\
\text { BMP2 alone) } \\
{[46]}\end{array}$ \\
\hline $\begin{array}{l}\text { Das et al. } 2015 \\
\text { [47] }\end{array}$ & BMP6 & PLGA & $\begin{array}{c}\text { Rat } \\
\text { Mandibular defect } \\
(2 / 8 / 12 \text { weeks })\end{array}$ & Simultaneous & $1: 1$ & $\begin{array}{c}\text { Enhanced (compared to } \\
\text { BMP6 alone) } \\
{[47]}\end{array}$ \\
\hline $\begin{array}{l}\text { Lv et al. } 2015 \\
{[48]}\end{array}$ & BMP2 & Fibrin glue (fast release) & $\begin{array}{c}\text { Rabbit } \\
\text { Femoral condyle defect } \\
\text { (4 weeks })\end{array}$ & Simultaneous & $1: 100$ & $\begin{array}{c}\text { No synergistic effect } \\
\text { (compared to BMP2 } \\
\text { alone) } \\
{[48]}\end{array}$ \\
\hline
\end{tabular}

sustained delivery at a low level in later stage. The optimal delivery manner of VEGF needs to be further studied. In addition, combining other angiogenic factors, such as PDGF, to facilitate the maturity and stability of neovascularization may be more effective [95].

Although some authors reported that fast release of BMP2 might induce more ectopic bone regeneration than its sustained release [13], more papers confirmed that the sustained delivery strategy would prolong its activity and reduce its potential side effects [7, 43, 97-101].

3.3. Ratio of VEGF to BMPs. The ratio of VEGF to BMPs has an obvious impact on their synergistic effects. Although the interactions between BMPs and VEGF are inconsistent 
among different kinds of BMPs, there is a similar trend that VEGF seems to be more effective at low ratio of VEGF/BMPs than at a high ratio $[19,20]$. Peng et al. [19] have adopted the cotransplantation of VEGF- and BMP4-expressing musclederived stem cells at different ratios to study its relationship with bone formation. The amount of bone formation in groups with the ratios of VEGF/BMP4 at 1:5 and 1:1 was significantly larger compared to that in the group with a ratio of $5: 1$ [19]. The interactions of VEGF and BMPs are based on their influence on the function and differentiation of target cells. Under high ratio of VEGF/BMPs, excessive VEGF will push local MSCs towards an endothelial lineage, reducing the cells available for osteogenic differentiation [19, 44]. It was reported that high dose of VEGF might lead to hemangiomalike tissue formation $[102,103]$. It was also suspected that high ratio of VEGF/BMPs may increase the recruitment and survival of osteoclasts, leading to excessive bone resorption [15, 104-106]. However, Peng et al. [19] disagreed with this. In their study, the markers of osteoclasts were similar in groups with low and high ratios of VEGF/BMP4 [19]. It is important to note that ratio of VEGF/BMPs reported in most studies is the ratio of total dose of growth factors $[42,44]$ or total amount of transfected cells used $[19,20]$. However, what actually affects the bone formation is the ratio of released growth factors. As reported by Lohse et al. [83], continuous delivery of VEGF and BMP2 at a ratio approximately 1 could significantly increase the induced bone formation compared to that at a ratio $\leq 0.5$. Future studies should further investigate the relationship between the ratio of released VEGF/BMPs and the amount of bone formation both in vitro and in vivo.

3.4. Animal Models. When other experimental conditions are controlled to be consistent, the synergistic effects of VEGF and BMPs vary among different animal models. In the same studies [13, 43], synergistic effects between VEGF and BMPs were only observed in ectopic models, while being absent in orthopaedic sites, indicating the synergistic effect was location-dependent. Facilitating the recruitment of MSCs is one of the mechanisms why VEGF can enhance bone formation elicited by BMPs. Nevertheless, in the bone defect site, periosteum and exposed marrow cavity can offer an abundant of MSCs [43]. Furthermore, local hematoma in orthopaedic site may serve as a source of endogenous angiogenic factors [48, 107-109]. The abundant source of MSCs and increased endogenous angiogenic factors may decrease the effect of exogenous VEGF. The synergistic effects between VEGF and BMPs are supposed to be more prominent in areas suffering from compromised circulation, such as ischemia model and old bone defect model.

3.5. Assessment Time. The synergistic effects of VEGF and BMPs might be observed in a short study period, while being absent in an extended period $[42,46]$. The decrease of concentration of growth factors, such as VEGF, may partly explain this, as analyzed above. Another possibility proposed in this review is whether the application of exogenous growth factors will downregulate the secretion of endogenous VEGF and BMPs within a certain period. If so, after depletion of exogenous growth factors, the lack of endogenous growth factors will be detrimental to bone regeneration. Extending observation period and setting different time points should be helpful to get further understanding of the synergistic effects and to optimize the combination application strategies in the future studies.

3.6. Other Influencing Factors. In addition to the factors mentioned above, material carriers of the delivery system, methods used in assessment of bone formation, and the introduction of other growth factors or cells might also influence the evaluation of synergistic effects of VEGF and BMPs. Effective control of these related factors can help us to get further understanding of the mechanisms of the interactions between these two key growth factors in angiogenesis and osteogenesis.

\section{Conclusions}

The combined delivery of VEGF and BMPs is a novel and promising strategy in bone tissue engineering. VEGF can help to promote the construction of vascular network, to improve the local supply of oxygen and nutrients, to increase the recruitment and survival of MSCs, and to enhance the response of MSCs to BMPs. When they are used in a combined delivery manner in vivo, VEGF has the potential to synergistically enhance BMPs induced bone formation. Many studies have been conducted to investigate the effect of this approach. However, due to the variation of BMPs, carriers of growth factors, controlled release manners, growth factors ratio, models, and assessment time, their results are pretty controversial. These influencing factors were identified and analyzed in this review to avoid more confusion on this issue. Future studies should further investigate the mechanisms of their synergistic effects and optimize these influencing factors to generate more effective bone regeneration.

\section{Disclosure}

Bo Li and Hai Wang are the first co-authors.

\section{Competing Interests}

The authors declare that they have no conflict of interests.

\section{Acknowledgments}

This work was supported by grants from Peking Union Medical College Youth Fund (no. 33320140019) and Peking Union Medical College graduate student innovation Fund (no. B2014001060).

\section{References}

[1] Y. Liu, J. Lim, and S.-H. Teoh, "Review: development of clinically relevant scaffolds for vascularised bone tissue engineering," Biotechnology Advances, vol. 31, no. 5, pp. 688-705, 2013. 
[2] R. J. O'Keefe and J. Mao, "Bone tissue engineering and regeneration: from discovery to the clinic-an overview," Tissue Engineering-Part B: Reviews, vol. 17, no. 6, pp. 389-392, 2011.

[3] C.-H. Lu, Y.-H. Chang, S.-Y. Lin, K.-C. Li, and Y.-C. Hu, "Recent progresses in gene delivery-based bone tissue engineering," Biotechnology Advances, vol. 31, no. 8, pp. 1695-1306, 2013.

[4] A. J. Salgado, O. P. Coutinho, and R. L. Reis, "Bone tissue engineering: state of the art and future trends," Macromolecular Bioscience, vol. 4, no. 8, pp. 743-765, 2004.

[5] U. Kneser, D. J. Schaefer, E. Polykandriotis, and R. E. Horch, "Tissue engineering of bone: the reconstructive surgeon's point of view," Journal of Cellular and Molecular Medicine, vol. 10, no. 1, pp. 7-19, 2006.

[6] M. D. Kofron and C. T. Laurencin, "Bone tissue engineering by gene delivery," Advanced Drug Delivery Reviews, vol. 58, no. 4, pp. 555-576, 2006.

[7] W. Zhang, X. Wang, S. Wang et al., "The use of injectable sonication-induced silk hydrogel for $\mathrm{VEGF}_{165}$ and BMP-2 delivery for elevation of the maxillary sinus floor," Biomaterials, vol. 32, no. 35, pp. 9415-9424, 2011.

[8] J. R. Lieberman, A. Daluiski, and T. A. Einhorn, "The role of growth factors in the repair of bone. Biology and clinical applications," Journal of Bone and Joint Surgery-Series A, vol. 84, no. 6, pp. 1032-1044, 2002.

[9] J. R. Lieberman, A. Daluiski, S. Stevenson et al., "The effect of regional gene therapy with bone morphogenetic protein2-producing bone-marrow cells on the repair of segmental femoral defects in rats," Journal of Bone and Joint SurgerySeries A, vol. 81, no. 7, pp. 905-917, 1999.

[10] M. R. Urist, "Bone: formation by autoinduction," Science, vol. 150, no. 3698, pp. 893-899, 1965.

[11] M. R. Urist and B. S. Strates, "Bone morphogenetic protein," Journal of Dental Research, vol. 50, no. 6, pp. 1392-1406, 1971.

[12] P. C. Bessa, M. Casal, and R. L. Reis, "Bone morphogenetic proteins in tissue engineering: the road from the laboratory to the clinic, part I (basic concepts)," Journal of Tissue Engineering and Regenerative Medicine, vol. 2, no. 1, pp. 1-13, 2008.

[13] R. E. Geuze, L. F. H. Theyse, D. H. R. Kempen et al., "A differential effect of bone morphogenetic protein-2 and vascular endothelial growth factor release timing on osteogenesis at ectopic and orthotopic sites in a large-animal model," Tissue Engineering - Part A, vol. 18, no. 19-20, pp. 2052-2062, 2012.

[14] P. C. Bessa, M. Casal, and R. L. Reis, "Bone morphogenetic proteins in tissue engineering: the road from laboratory to clinic, part II (BMP delivery)," Journal of Tissue Engineering and Regenerative Medicine, vol. 2, no. 2-3, pp. 81-96, 2008.

[15] Q. Cui, A. S. Dighe, and J. N. Irvine Jr., "Combined angiogenic and osteogenic factor delivery for bone regenerative engineering," Current Pharmaceutical Design, vol. 19, no. 19, pp. 33743383, 2013.

[16] A. Mesfin, J. M. Buchowski, L. P. Zebala et al., "High-dose rhBMP-2 for adults: major and minor complications: a study of 502 spine cases," Journal of Bone and Joint Surgery-Series A, vol. 95, no. 17, pp. 1546-1553, 2013.

[17] R. Fu, S. Selph, M. McDonagh et al., "Effectiveness and harms of recombinant human bone morphogenetic protein-2 in spine fusion: a systematic review and meta-analysis," Annals of Internal Medicine, vol. 158, no. 12, pp. 890-902, 2013.

[18] D. Gothard, E. L. Smith, J. M. Kanczler et al., "Tissue engineered bone using select growth factors: a comprehensive review of animal studies and clinical translation studies in man," European Cells and Materials, vol. 28, pp. 166-207, 2014.
[19] H. Peng, V. Wright, A. Usas et al., "Synergistic enhancement of bone formation and healing by stem cell-expressed VEGF and bone morphogenetic protein-4," Journal of Clinical Investigation, vol. 110, no. 6, pp. 751-759, 2002.

[20] H. Peng, A. Usas, A. Olshanski et al., "VEGF improves, whereas sFlt1 inhibits, BMP2-induced bone formation and bone healing through modulation of angiogenesis," Journal of Bone and Mineral Research, vol. 20, no. 11, pp. 2017-2027, 2005.

[21] M. Samee, S. Kasugai, H. Kondo, K. Ohya, H. Shimokawa, and S. Kuroda, "Bone morphogenetic protein-2 (BMP-2) and vascular endothelial growth factor (VEGF) transfection to human periosteal cells enhances osteoblast differentiation and bone formation," Journal of Pharmacological Sciences, vol. 108, no. 1, pp. 18-31, 2008.

[22] G. Li, K. Corsi-Payne, B. Zheng, A. Usas, H. Peng, and J. Huard, "The dose of growth factors influences the synergistic effect of vascular endothelial growth factor on bone morphogenetic protein 4-induced ectopic bone formation," Tissue EngineeringPart A, vol. 15, no. 8, pp. 2123-2133, 2009.

[23] F. Cui, X. Wang, X. Liu, A. S. Dighe, G. Balian, and Q. Cui, "VEGF and BMP-6 enhance bone formation mediated by cloned mouse osteoprogenitor cells," Growth Factors, vol. 28, no. 5, pp. 306-317, 2010.

[24] C. Xiao, H. Zhou, G. Liu et al., "Bone marrow stromal cells with a combined expression of BMP-2 and VEGF-165 enhanced bone regeneration," Biomedical Materials, vol. 6, no. 1, Article ID 015013, 2011.

[25] M. Lovett, K. Lee, A. Edwards, and D. L. Kaplan, "Vascularization strategies for tissue engineering," Tissue Engineering - Part B: Reviews, vol. 15, no. 3, pp. 353-370, 2009.

[26] R. K. Jain, P. Au, J. Tam, D. G. Duda, and D. Fukumura, "Engineering vascularized tissue," Nature Biotechnology, vol. 23, no. 7, pp. 821-823, 2005.

[27] C. Fidkowski, M. R. Kaazempur-Mofrad, J. Borenstein, J. P. Vacanti, R. Langer, and Y. Wang, "Endothelialized microvasculature based on a biodegradable elastomer," Tissue Engineering, vol. 11, no. 1-2, pp. 302-309, 2005.

[28] U. Saran, S. Gemini Piperni, and S. Chatterjee, "Role of angiogenesis in bone repair," Archives of Biochemistry and Biophysics, vol. 561, pp. 109-117, 2014.

[29] H.-P. Gerber, T. H. Vu, A. M. Ryan, J. Kowalski, Z. Werb, and N. Ferrara, "VEGF couples hypertrophic cartilage remodeling, ossification and angiogenesis during endochondral bone formation," Nature Medicine, vol. 5, no. 6, pp. 623-628, 1999.

[30] S. Mori, H. Yoshikawa, J. Hashimoto et al., "Antiangiogenic agent (TNP-470) inhibition of ectopic bone formation induced by bone morphogenetic protein-2," Bone, vol. 22, no. 2, pp. 99105, 1998.

[31] M. R. Hausman, M. B. Schaffler, and R. J. Majeska, "Prevention of fracture healing in rats by an inhibitor of angiogenesis," Bone, vol. 29, no. 6, pp. 560-564, 2001.

[32] D. Kaigler, Z. Wang, K. Horger, D. J. Mooney, and P. H. Krebsbach, "VEGF scaffolds enhance angiogenesis and bone regeneration in irradiated osseous defects," Journal of Bone and Mineral Research, vol. 21, no. 5, pp. 735-744, 2006.

[33] A. H. Zisch, M. P. Lutolf, and J. A. Hubbell, "Biopolymeric delivery matrices for angiogenic growth factors," Cardiovascular Pathology, vol. 12, no. 6, pp. 295-310, 2003.

[34] A. H. Zisch, M. P. Lutolf, M. Ehrbar et al., "Cell-demanded release of VEGF from synthetic, biointeractive cell ingrowth matrices for vascularized tissue growth," FASEB Journal, vol. 17, no. 15 , pp. 2260-2262, 2003. 
[35] S. M. Bauer, R. J. Bauer, Z.-J. Liu, H. Chen, L. Goldstein, and O. C. Velazquez, "Vascular endothelial growth factor-C promotes vasculogenesis, angiogenesis, and collagen constriction in three-dimensional collagen gels," Journal of Vascular Surgery, vol. 41, no. 4, pp. 699-707, 2005.

[36] J. Andrae, R. Gallini, and C. Betsholtz, "Role of plateletderived growth factors in physiology and medicine," Genes and Development, vol. 22, no. 10, pp. 1276-1312, 2008.

[37] A. Perets, Y. Baruch, F. Weisbuch, G. Shoshany, G. Neufeld, and S. Cohen, "Enhancing the vascularization of three-dimensional porous alginate scaffolds by incorporating controlled release basic fibroblast growth factor microspheres," Journal of Biomedical Materials Research-Part A, vol. 65, no. 4, pp. 489-497, 2003.

[38] Y.-H. Kim and Y. Tabata, "Dual-controlled release system of drugs for bone regeneration," Advanced Drug Delivery Reviews, vol. 94, pp. 28-40, 2015.

[39] J. M. Kanczler and R. O. C. Oreffo, "Osteogenesis and angiogenesis: the potential for engineering bone," European Cells and Materials, vol. 15, pp. 100-114, 2008.

[40] R. Subbiah, M. P. Hwang, S. Y. Van et al., "Osteogenic/ angiogenic dual growth factor delivery microcapsules for regeneration of vascularized bone tissue," Advanced Healthcare Materials, vol. 4, no. 13, pp. 1982-1992, 2015.

[41] N. Kakudo, K. Kusumoto, Y. B. Wang, Y. Iguchi, and Y. Ogawa, "Immunolocalization of vascular endothelial growth factor on intramuscular ectopic osteoinduction by bone morphogenetic protein-2," Life Sciences, vol. 79, no. 19, pp. 1847-1855, 2006.

[42] Z. S. Patel, S. Young, Y. Tabata, J. A. Jansen, M. E. K. Wong, and A. G. Mikos, "Dual delivery of an angiogenic and an osteogenic growth factor for bone regeneration in a critical size defect model," Bone, vol. 43, no. 5, pp. 931-940, 2008.

[43] D. H. R. Kempen, L. Lu, A. Heijink et al., "Effect of local sequential VEGF and BMP-2 delivery on ectopic and orthotopic bone regeneration," Biomaterials, vol. 30, no. 14, pp. 2816-2825, 2009.

[44] S. Young, Z. S. Patel, J. D. Kretlow et al., "Dose effect of dual delivery of vascular endothelial growth factor and bone morphogenetic protein- 2 on bone regeneration in a rat criticalsize defect model," Tissue Engineering_Part A, vol. 15, no. 9, pp. 2347-2362, 2009.

[45] J. C. Roldán, R. Detsch, S. Schaefer et al., "Bone formation and degradation of a highly porous biphasic calcium phosphate ceramic in presence of BMP-7, VEGF and mesenchymal stem cells in an ectopic mouse model," Journal of CranioMaxillofacial Surgery, vol. 38, no. 6, pp. 423-430, 2010.

[46] A. Hernández, R. Reyes, E. Sánchez, M. Rodríguez-Évora, A. Delgado, and C. Évora, "In vivo osteogenic response to different ratios of BMP-2 and VEGF released from a biodegradable porous system," Journal of Biomedical Materials Research Part A, vol. 100, no. 9, pp. 2382-2391, 2012.

[47] A. Das, B. A. Fishero, J. J. Christophel et al., "Poly(lactic-coglycolide) polymer constructs cross-linked with human BMP6 and VEGF protein significantly enhance rat mandible defect repair," Cell and Tissue Research, 2015.

[48] J. Lv, P. Xiu, J. Tan, Z. Jia, H. Cai, and Z. Liu, "Enhanced angiogenesis and osteogenesis in critical bone defects by the controlled release of BMP-2 and VEGF: implantation of electron beam melting-fabricated porous $\mathrm{Ti}_{6} \mathrm{Al}_{4} \mathrm{~V}$ scaffolds incorporating growth factor-doped fibrin glue," Biomedical Materials (Bristol), vol. 10, no. 3, Article ID 035013, 2015.
[49] G. Neufeld, T. Cohen, S. Gengrinovitch, and Z. Poltorak, "Vascular endothelial growth factor (VEGF) and its receptors," The FASEB Journal, vol. 13, no. 1, pp. 9-22, 1999.

[50] Y. Zhang, V. Madhu, A. S. Dighe, J. N. Irvine Jr., and Q. Cui, "Osteogenic response of human adipose-derived stem cells to BMP-6, VEGF, and combined VEGF plus BMP-6 in vitro," Growth Factors, vol. 30, no. 5, pp. 333-343, 2012.

[51] V. Madhu, C.-J. Li, A. S. Dighe, G. Balian, and Q. Cui, "BMP-non-responsive $\mathrm{Scal}^{+} \mathrm{CD} 73^{+} \mathrm{CD} 44^{+}$mouse bone marrow derived osteoprogenitor cells respond to combination of VEGF and BMP-6 to display enhanced osteoblastic differentiation and ectopic bone formation," PLOS ONE, vol. 9, no. 7, Article ID e103060, 2014.

[52] Q. Kang, M. H. Sun, H. Cheng et al., "Characterization of the distinct orthotopic bone-forming activity of 14 BMPs using recombinant adenovirus-mediated gene delivery," Gene Therapy, vol. 11, no. 17, pp. 1312-1320, 2004.

[53] M. P. G. Bostrom, J. M. Lane, W. S. Berberian et al., "Immunolocalization and expression of bone morphogenetic proteins 2 and 4 in fracture healing," Journal of Orthopaedic Research, vol. 13, no. 3, pp. 357-367, 1995.

[54] G. Wei, Q. Jin, W. V. Giannobile, and P. X. Ma, "The enhancement of osteogenesis by nano-fibrous scaffolds incorporating rhBMP-7 nanospheres," Biomaterials, vol. 28, no. 12, pp. 20872096, 2007.

[55] M. T. Wolf, C. L. Dearth, S. B. Sonnenberg, E. G. Loboa, and S. F. Badylak, "Naturally derived and synthetic scaffolds for skeletal muscle reconstruction," Advanced Drug Delivery Reviews, vol. 84, pp. 208-221, 2015.

[56] S. Almubarak, H. Nethercott, M. Freeberg et al., "Tissue engineering strategies for promoting vascularized bone regeneration," Bone, vol. 83, pp. 197-209, 2016.

[57] A. C. Mitchell, P. S. Briquez, J. A. Hubbell, and J. R. Cochran, "Engineering growth factors for regenerative medicine applications," Acta Biomaterialia, vol. 30, pp. 1-12, 2016.

[58] E. Pola, W. Gao, Y. Zhou et al., "Efficient bone formation by gene transfer of human LIM mineralization protein-3," Gene Therapy, vol. 11, no. 8, pp. 683-693, 2004.

[59] S. Yang, D. Wei, D. Wang, M. Phimphilai, P. H. Krebsbach, and R. T. Franceschi, "In vitro and in vivo synergistic interactions between the Runx2/Cbfal transcription factor and bone morphogenetic protein-2 in stimulating osteoblast differentiation," Journal of Bone and Mineral Research, vol. 18, no. 4, pp. 705-715, 2003.

[60] B. Peterson, J. Zhang, R. Iglesias et al., "Healing of critically sized femoral defects, using genetically modified mesenchymal stem cells from human adipose tissue," Tissue Engineering, vol. 11, no. 1-2, pp. 120-129, 2005.

[61] H.-C. Shen, H. Peng, A. Usas, B. Gearhart, F. H. Fu, and J. Huard, "Structural and functional healing of critical-size segmental bone defects by transduced muscle-derived cells expressing BMP4," Journal of Gene Medicine, vol. 6, no. 9, pp. 984-991, 2004.

[62] M. Yang, Q.-J. Ma, G. T. Dang, K. T. Ma, P. Chen, and C.-Y. Zhou, "In vitro and in vivo induction of bone formation based on ex vivo gene therapy using rat adipose-derived adult stem cells expressing BMP-7," Cytotherapy, vol. 7, no. 3, pp. 273-281, 2005.

[63] H.-L. Lee, H. Y. Lee, Y. Yun et al., "Hypoxia-specific, VEGFexpressing neural stem cell therapy for safe and effective treatment of neuropathic pain," Journal of Controlled Release, vol. 226, pp. 21-34, 2016. 
[64] J. Su, H. Xu, J. Sun, X. Gong, and H. Zhao, "Dual delivery of BMP-2 and bFGF from a new nano-composite scaffold, loaded with vascular stents for large-size mandibular defect regeneration," International Journal of Molecular Sciences, vol. 14, no. 6, pp. 12714-12728, 2013.

[65] L. Lei, S. Wang, H. Wu et al., "Optimization of release pattern of FGF-2 and BMP-2 for osteogenic differentiation of lowpopulation density hMSCs," Journal of Biomedical Materials Research-Part A, vol. 103, no. 1, pp. 252-261, 2015.

[66] S. Facca, C. Cortez, C. Mendoza-Palomares et al., "Active multilayered capsules for in vivo bone formation," Proceedings of the National Academy of Sciences of the United States of America, vol. 107, no. 8, pp. 3406-3411, 2010.

[67] B. De la Riva, E. Sánchez, A. Hernández et al., "Local controlled release of VEGF and PDGF from a combined brushite-chitosan system enhances bone regeneration," Journal of Controlled Release, vol. 143, no. 1, pp. 45-52, 2010.

[68] B. S. Kim, J. S. Kim, S. S. Yang, H. W. Kim, H. J. Lim, and J. Lee, "Angiogenin-loaded fibrin/bone powder composite scaffold for vascularized bone regeneration," Biomaterials Research, vol. 19, article 18, 2015.

[69] Y. Gao, S. Zhu, E. Luo, J. Li, G. Feng, and J. Hu, "Basic fibroblast growth factor suspended in Matrigel improves titanium implant fixation in ovariectomized rats," Journal of Controlled Release, vol. 139, no. 1, pp. 15-21, 2009.

[70] Y. J. Jung, K. Kim, J. Heo et al., "Induction of angiogenesis by matrigel coating of VEGF-loaded PEG/PCL-based hydrogel scaffolds for hbmsc transplantation," Molecules and Cells, vol. 38, no. 7, pp. 663-668, 2015.

[71] C. H. Evans and J. Huard, "Gene therapy approaches to regenerating the musculoskeletal system," Nature Reviews Rheumatology, vol. 11, no. 4, pp. 234-242, 2015.

[72] J. T. Sieker, M. Kunz, M. Weißenberger et al., "Direct bone morphogenetic protein 2 and Indian hedgehog gene transfer for articular cartilage repair using bone marrow coagulates," Osteoarthritis and Cartilage, vol. 23, no. 3, pp. 433-442, 2015.

[73] V. J. Wright, H. Peng, A. Usas et al., "BMP4-expressing musclederived stem cells differentiate into osteogenic lineage and improve bone healing in immunocompetent mice," Molecular Therapy, vol. 6, no. 2, pp. 169-178, 2002.

[74] L. Zhu, D. Chuanchang, L. Wei, C. Yilin, and D. Jiasheng, "Enhanced healing of goat femur-defect using BMP7 genemodified BMSCs and load-bearing tissue-engineered bone," Journal of Orthopaedic Research, vol. 28, no. 3, pp. 412-418, 2010.

[75] R. Li, D. J. Stewart, H. P. Von Schroeder, E. S. Mackinnon, and E. H. Schemitsch, "Effect of cell-based VEGF gene therapy on healing of a segmental bone defect," Journal of Orthopaedic Research, vol. 27, no. 1, pp. 8-14, 2009.

[76] C. Hélary and M. F. Desimone, "Recent advances in biomaterials for tissue engineering and controlled drug delivery," Current Pharmaceutical Biotechnology, vol. 16, no. 7, pp. 635-645, 2015.

[77] T. Kaito, A. Myoui, K. Takaoka et al., "Potentiation of the activity of bone morphogenetic protein-2 in bone regeneration by a PLA-PEG/hydroxyapatite composite," Biomaterials, vol. 26, no. 1, pp. 73-79, 2005.

[78] Y. Yonamine, T. Matsuyama, T. Sonomura et al., "Effectable application of vascular endothelial growth factor to critical sized rat calvaria defects," Oral Surgery, Oral Medicine, Oral Pathology, Oral Radiology and Endodontology, vol. 109, no. 2, pp. 225-231, 2010.

[79] Y.-C. Huang, D. Kaigler, K. G. Rice, P. H. Krebsbach, and D. J. Mooney, "Combined angiogenic and osteogenic factor delivery enhances bone marrow stromal cell-driven bone regeneration," Journal of Bone and Mineral Research, vol. 20, no. 5, pp. 848-857, 2005.

[80] T. Luo, W. Zhang, B. Shi, X. Cheng, and Y. Zhang, "Enhanced bone regeneration around dental implant with bone morphogenetic protein 2 gene and vascular endothelial growth factor protein delivery," Clinical Oral Implants Research, vol. 23, no. 4, pp. 467-473, 2012.

[81] M. Ramazanoglu, R. Lutz, C. Ergun, C. von Wilmowsky, E. Nkenke, and K. A. Schlegel, "The effect of combined delivery of recombinant human bone morphogenetic protein-2 and recombinant human vascular endothelial growth factor 165 from biomimetic calcium-phosphate-coated implants on osseointegration," Clinical Oral Implants Research, vol. 22, no. 12, pp. 1433-1439, 2011.

[82] C. Schmitt, R. Lutz, H. Doering, M. Lell, J. Ratky, and K. A. Schlegel, "Bio-Oss ${ }^{\circledR}$ blocks combined with BMP-2 and VEGF for the regeneration of bony defects and vertical augmentation," Clinical Oral Implants Research, vol. 24, no. 4, pp. 450-460, 2013.

[83] N. Lohse, N. Moser, S. Backhaus, T. Annen, M. Epple, and H. Schliephake, "Continuous delivery of rhBMP2 and rhVEGF165 at a certain ratio enhances bone formation in mandibular defects over the delivery of rhBMP2 alone-An experimental study in rats," Journal of Controlled Release, vol. 220, pp. 201209, 2015.

[84] H. Wang, G. Wu, J. Zhang et al., "Osteogenic effect of controlled released rhBMP-2 in 3D printed porous hydroxyapatite scaffold," Colloids and Surfaces B: Biointerfaces, vol. 141, pp. 491-498, 2016.

[85] H. Ueda, L. Hong, M. Yamamoto et al., "Use of collagen sponge incorporating transforming growth factor- $\beta 1$ to promote bone repair in skull defects in rabbits," Biomaterials, vol. 23, no. 4, pp. 1003-1010, 2002.

[86] Y. Tabata, K. Yamada, S. Miyamoto et al., "Bone regeneration by basic fibroblast growth factor complexed with biodegradable hydrogels," Biomaterials, vol. 19, no. 7-9, pp. 807-815, 1998.

[87] F. M. Phillips, A. S. Turner, H. B. Seim III et al., "In vivo BMP7 (OP-1) enhancement of osteoporotic vertebral bodies in an ovine model," Spine Journal, vol. 6, no. 5, pp. 500-506, 2006.

[88] K. Sojo, Y. Sawaki, H. Hattori, H. Mizutani, and M. Ueda, "Immunohistochemical study of vascular endothelial growth factor (VEGF) and bone morphogenetic protein-2, -4 (BMP-2, -4) on lengthened rat femurs," Journal of Cranio-Maxillofacial Surgery, vol. 33, no. 4, pp. 238-245, 2005.

[89] S. Uchida, A. Sakai, H. Kudo et al., "Vascular endothelial growth factor is expressed along with its receptors during the healing process of bone and bone marrow after drill-hole injury in rats," Bone, vol. 32, no. 5, pp. 491-501, 2003.

[90] T. Pufe, B. Wildemann, W. Petersen, R. Mentlein, M. Raschke, and G. Schmidmaier, "Quantitative measurement of the splice variants 120 and 164 of the angiogenic peptide vascular endothelial growth factor in the time flow of fracture healing: a study in the rat," Cell and Tissue Research, vol. 309, no. 3, pp. 387-392, 2002.

[91] T.-J. Cho, L. C. Gerstenfeld, and T. A. Einhorn, "Differential temporal expression of members of the transforming growth factor $\beta$ superfamily during murine fracture healing," Journal of Bone and Mineral Research, vol. 17, no. 3, pp. 513-520, 2002.

[92] T. Niikura, D. J. Hak, and A. Hari Reddi, "Global gene profiling reveals a downregulation of BMP gene expression in experimental atrophic nonunions compared to standard healing 
fractures," Journal of Orthopaedic Research, vol. 24, no. 7, pp. 1463-1471, 2006.

[93] H. M. Blau and A. Banfi, "The well-tempered vessel," Nature Medicine, vol. 7, no. 5, pp. 532-534, 2001.

[94] P. Carmeliet and R. K. Jain, "Angiogenesis in cancer and other diseases," Nature, vol. 407, no. 6801, pp. 249-257, 2000.

[95] T. P. Richardson, M. C. Peters, A. B. Ennett, and D. J. Mooney, "Polymeric system for dual growth factor delivery," Nature Biotechnology, vol. 19, no. 11, pp. 1029-1034, 2001.

[96] L. E. Benjamin, D. Golijanin, A. Itin, D. Pode, and E. Keshet, "Selective ablation of immature blood vessels in established human tumors follows vascular endothelial growth factor withdrawal," The Journal of Clinical Investigation, vol. 103, no. 2, pp. 159-165, 1999.

[97] J. E. Samorezov, E. B. Headley, C. R. Everett, and E. Alsberg, "Sustained presentation of BMP-2 enhances osteogenic differentiation of human adipose-derived stem cells in gelatin hydrogels," Journal of Biomedical Materials Research-Part A, vol. 104, no. 6, pp. 1387-1397, 2016.

[98] K. Park, "Biodegradable thermosensitive polymer gel for sustained BMP-2 delivery," Journal of Controlled Release, vol. 209, p. $337,2015$.

[99] B.-B. Seo, H. Choi, J.-T. Koh, and S.-C. Song, "Sustained BMP-2 delivery and injectable bone regeneration using thermosensitive polymeric nanoparticle hydrogel bearing dual interactions with BMP-2," Journal of Controlled Release, vol. 209, pp. 67-76, 2015.

[100] M. Faßbender, S. Minkwitz, C. Strobel, G. Schmidmaier, and B. Wildemann, "Stimulation of bone healing by sustained bone morphogenetic protein 2 (BMP-2) delivery," International Journal of Molecular Sciences, vol. 15, no. 5, pp. 8539-8552, 2014.

[101] M. T. Poldervaart, H. Wang, J. Van Der Stok et al., "Sustained release of BMP-2 in bioprinted alginate for osteogenicity in mice and rats," PLoS ONE, vol. 8, no. 8, Article ID e72610, 2013.

[102] M. L. Springer, A. S. Chen, P. E. Kraft, M. Bednarski, and H. M. Blau, "VEGF gene delivery to muscle: potential role for vasculogenesis in adults," Molecular Cell, vol. 2, no. 5, pp. 549$558,1998$.

[103] R. J. Lee, M. L. Springer, W. E. Blanco-Bose, R. Shaw, P. C. Ursell, and H. M. Blau, "VEGF gene delivery to myocardium: deleterious effects of unregulated expression," Circulation, vol. 102, no. 8, pp. 898-901, 2000.

[104] M. T. Engsig, Q.-J. Chen, T. H. Vu et al., "Matrix metalloproteinase 9 and vascular endothelial growth factor are essential for osteoclast recruitment into developing long bones," Journal of Cell Biology, vol. 151, no. 4, pp. 879-889, 2000.

[105] Q. Yang, K. P. McHugh, S. Patntirapong, X. Gu, L. Wunderlich, and P. V. Hauschka, "VEGF enhancement of osteoclast survival and bone resorption involves VEGF receptor-2 signaling and 33-integrin," Matrix Biology, vol. 27, no. 7, pp. 589-599, 2008.

[106] K. Henriksen, M. Karsdal, J.-M. Delaissé, and M. T. Engsig, "RANKL and vascular endothelial growth factor (VEGF) induce osteoclast chemotaxis through an ERK1/2-dependent mechanism," The Journal of Biological Chemistry, vol. 278, no. 49, pp. 48745-48753, 2003.

[107] A. Weltermann, M. Wolzt, K. Petersmann et al., "Large amounts of vascular endothelial growth factor at the site of hemostatic plug formation in vivo," Arteriosclerosis, Thrombosis, and Vascular Biology, vol. 19, no. 7, pp. 1757-1760, 1999.

[108] G. Pintucci, S. Froum, J. Pinnell, P. Mignatti, S. Rafii, and D. Green, "Trophic effects of platelets on cultured endothelial cells are mediated by platelet-associated fibroblast growth factor2 (FGF-2) and vascular endothelial growth factor (VEGF)," Thrombosis and Haemostasis, vol. 88, no. 5, pp. 834-842, 2002.

[109] E. Anitua, I. Andia, B. Ardanza, P. Nurden, and A. T. Nurden, "Autologous platelets as a source of proteins for healing and tissue regeneration," Thrombosis and Haemostasis, vol. 91, no. 1, pp. 4-15, 2004. 


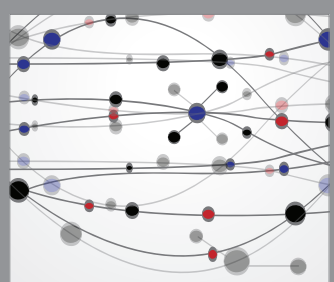

The Scientific World Journal
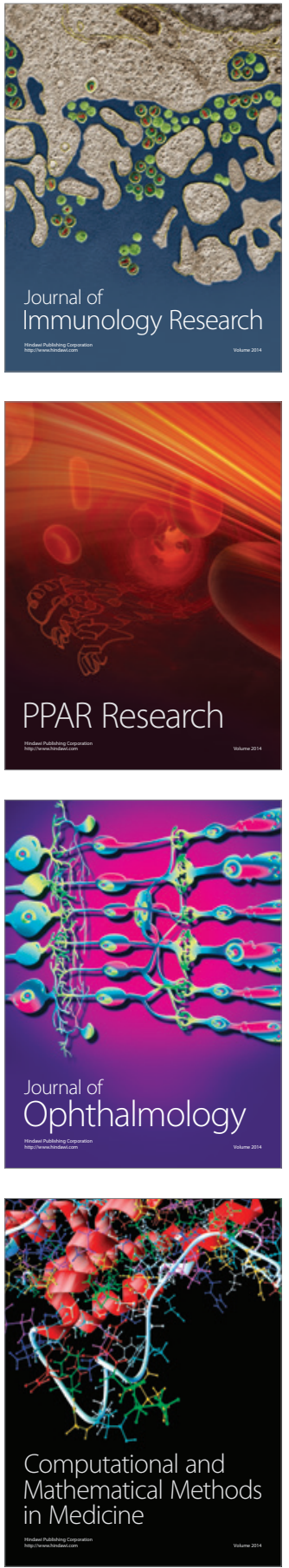

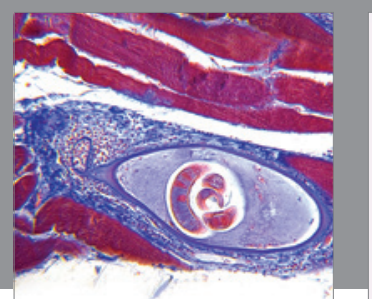

Gastroenterology Research and Practice

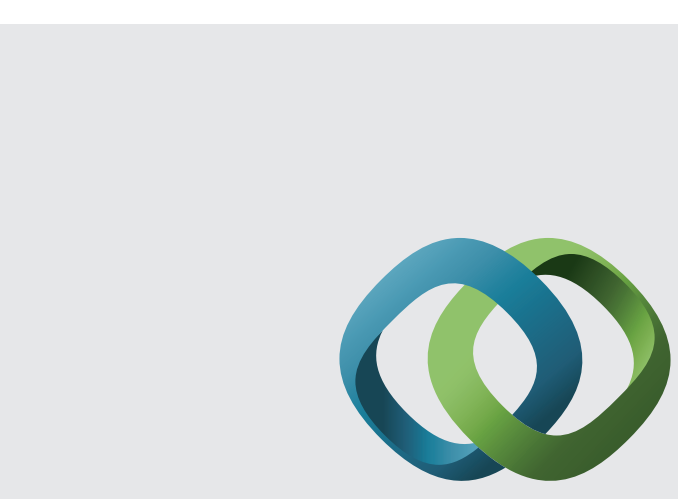

\section{Hindawi}

Submit your manuscripts at

http://www.hindawi.com
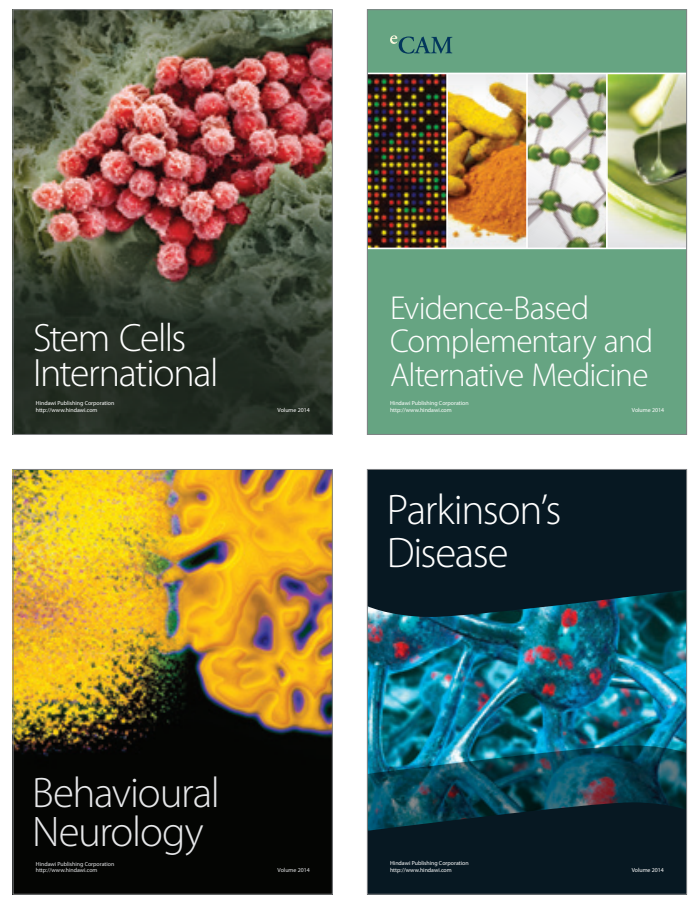
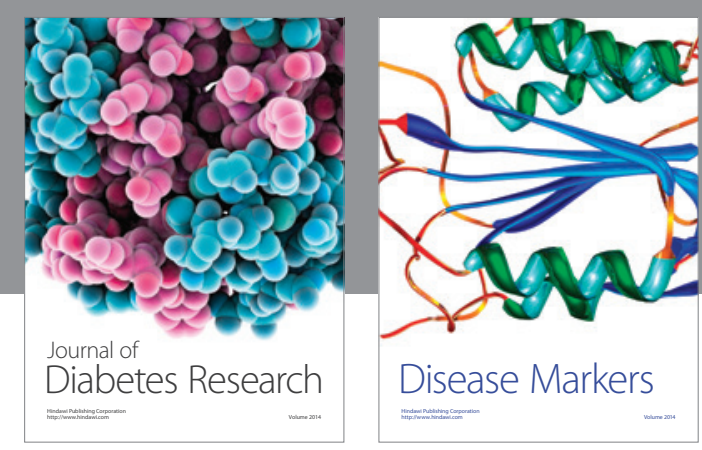

Disease Markers
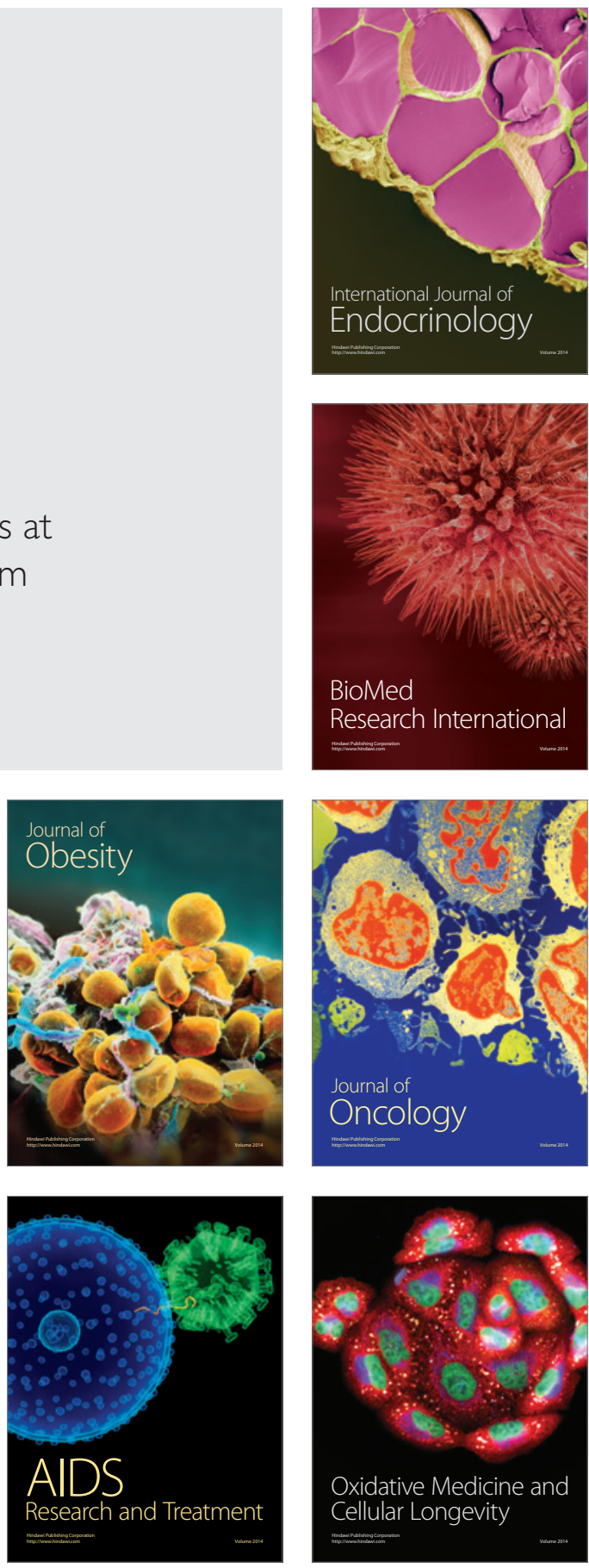